\title{
POST-JUDGMENT INTEREST - AVOIDING THE CANADA INTEREST ACT - NOT ANY MORE - FOR NOW \\ Dr. Eugene Meehan*
}

This is a follow-up comment to an article by the writer published in the Alberta Law Review. ${ }^{1}$ That article explained, based on 6 recent Alberta decisions, ${ }^{2}$ how the Canada Interest Act $5 \%$ maximum interest on judgments could be avoided in advance by proper drafting, and contained an appropriate clause by way of example.

The relevant sections of the Canada Interest Act are as follows:

Section 2: Except as otherwise provided by this or by any other Act of the Parliament of Canada, any person may stipulate for, allow and enact, on any contract or agreement whatever, any rate of interest or discount that is agreed upon.

Section 13: Every judgment debt shall bear interest at the rate of five percent per annum until it is satisfied. ${ }^{3}$

These 6 Alberta decisions, ${ }^{4}$ plus another 5 more-recently available, ${ }^{5}$ essentially took the view that post-judgment interest in excess of $5 \%$ could be contracted for in advance if the interest clause was appropriately

* LL.B. (Edinburgh), LL.M. (McGill), LL.B. (Ottawa), PH.D. (McGill); of the Faculty of Law, University of Alberta, and the Law Society of Alberta.

1. (1984) 22 Alberta Law Review 270.

2. Bank of Nova Scotia v. U.P.C. Holdings Ltd. (1980) 11 Alta. L.R. (2d) 331 (Alta. Q.B.); Spenrath Construction Ltd. v. 206763 Holdings Ltd. (1982) 32 A.R. 216 (Alta. Q.B., M.C.); Zero Stores (Sask.) Ltd. v. K.A.H. Investments Ltd., unreported, Oct. 5, 1982, J.D. Calgary, Appeal Sittings 14391; Heritage Savings and Trust Company v. Blow Out Prevention Equipment Services Ltd. et al., unreported, Aug. 25, 1983 (Alta. Q.B., M.C.); Bank of Nova Scotia v. R.P. \& R. Holdings Ltd. et al. (1982) 18 Alta. L.R. (2d) 193 (Alta. Q.B., M.C.); Maple Credit Ltd.v. Xomox Investments Ltd. et al. (1982) 21 Alta. L.R. (2d) 289 (Alta. Q.B., M.C.).

3. For a history of the Interest Act, and these sections in particular, see: Spenrath Construction Ltd. v. 206736 Holdings Ltd., supra note 1, pp. 228-231, and Canada Permanent Trust Company v. King Art Developments Lid. et al., unreported, 20 June 1984, Appeal Nos. 15851, 15992, 17085, 17196.

4. Supra, note 2.

5. Heritage Savings and Trust Company v. Uniram Holdings Ltd. et al., unreported, Jan. 3. 1984 (Alta. Q.B., M.C.); Tuscon Properties Ltd. v. Sentry Resources Ltd. et al., unreported, Aug. 19, 1982 (Alta. Q.B., M.C.); Tessier et al. v. Van Ed Block Developments Ltd., unreported, Mar. 1, 1982 (Alta. Q.B., M.C.); Commerce Capital Trust Company v. Kar Industries Ltd. et al., unreported, Oct. 1, 1981 (Alta. Q.B.); First Investors Corporation Ltd. et al. v. Golden Flow Developments [1982] Alta. D. 2778-03 (Alta. Q.B., M.C.). 


\section{and carefully drafted. ${ }^{6}$ For example, Master Funduk observed in one such case: ${ }^{7}$}

... I find that the parties can agree to a higher rate of interest on a judgment than the rate set by s. 13. The mortgage in this case expressly says so. The plaintiff is entitled to interest on the judgment for the deficiency in accordance with . . . its mortgage.

In some cases the interest clause was properly drafted, so that the higher contract rate of interest was recoverable, ${ }^{8}$ and in others it was not, the Court in the latter instances generally pointing out what was lacking in the particular clause. ${ }^{9}$

However, on June 20,1984, the Court of Appeal released a significant foreclosures decision, ${ }^{10}$ and also took the opportunity therein to express its views on post-judgment interest, as follows: ${ }^{11}$

[T]wo opposing interpretations turn on the opening two lines of Section 2. One interpretation suggested is that the provision which is to be regarded as an exception to Section 2 must itself state its prohibition. On this version Section 2 would be interpreted as stating that any person may stipulate for any rate of interest except where some Act of Parliament provides that he may not so stipulate. The other interpretation suggested is that any person may stipulate for any interest unless in some Act of Parliament a specific rate is fixed for that situation.

... In my view if the Act of Parliament which is to 'otherwise' provide must itself state the prohibition, there is no need to state it in Section 2. That result would be achieved by the prohibition in the other section without the opening two lines of Section 2 . Moreover, the contrary interpretation requires that Section 2 be read as though it says, 'Except as otherwise prohibited ...' In my view, it is 'otherwise provided' when the other section fixes a rate of interest applicable to a given situation.

I therefore conclude that the parties to this mortgage were not able to contract out of the provisions of Section 13 of The Interest Act and that the judgment must bear interest at 5 per cent. Unrealistic as is that rate of interest in modern times, the remedy is for the Parliament of Canada.

Post-judgment interest is therefore no longer permitted, no matter how one drafts the interest clause.

6. One had to provide in particular for the non-merger of the covenant to pay interest, or of any other covenant, and the continuing obligation to pay interest before and after maturity, default and judgment.

7. Spenrath Construction Ltd. v. 206763 Holdings Ltd. et al. (1982) 32 A.R. 216 at 232 (Alta. Q.B., M.C.). Stevenson, J., (as he then was):

"I am of the view that the parties here have not prescribed the payment of interest after judgment but rather the payment of interest on principal after as well as before default. ... express provisions must be employed in order that an agreed rate be applied after default. A fortiori it would require a further express provision to make the agreed rate apply after judgment." Bank of Nova Scotia v. U.P.C. Holdings Ltd., supra note 2 at 334-335.

See also the following cases at the pages indicated: Heritage Savings and Trust Company v. Blow Out Prevention Equipment Services Ltd. et al., supra note 2 at 1; Bank of Nova Scotia v. R.P. \& R. Holdings Ltd. et al., supra note 2 at 196-197; Zero Stores (Sask.) Ltd. v. K.A.H. Investments Ltd., supra note 2 at 8-10; Maple Credit Ltd. v. Xomox Investments Ltd. et al., supra note 2 at 292; Tessier et al. v. Van Ed Block Developments Ltd. et al., supra note 5 at 4-6; Heritage Savings and Trust Company v. Uniram Holdings et al., supra note 5 at 8; Tucson Properties Ltd. v. Sentry Resources $L t d$. et al., supra note 5 at 15-16; Commerce Capital Trust Companyv. Kar Industries Ltd. et al., supra note 5 at 6.

8. Spenrath Construction Ltd. v. 206763 Holdings Lid., supra note 2; Commerce Capital Trust Company v. Kar Industries Ltd. et al., supra note 5; First Investors Corporation Ltd. et al.v. Golden Flow Developments, supra note 5.

9. See the balance of the cases in notes 2 and 5 supra.

10. Canada Permanent Trust Company v. King Art Developments Ltd. et al., supra note 3.

11. Id. pp. 41-47, per Laycraft, J.A. 
In view of the total of 11 prior Alberta decisions on post-judgment interest, this principled proscription of interest beyond $5 \%$ is unexpected. The Court could have restricted its comments to the particular clause before it, as the previous Alberta decisions had done, but chose otherwise, referring only to $2^{12}$ of the 11 previous Alberta decisions. Further, this Court of Appeal decision is also surprising in view of the existence of an unreported 1982 judgment of the Alberta Court of Appeal, sitting in Calgary - which the Court also did not refer to - wherein the Court had taken an opposite tack: ${ }^{13}$
Where parties intend to contract out of such an express statutory provision as section 13 of The Interest Act, they must do so in the most clear and unambiguous terms. That re- quirement was laid down almost 100 years ago in the Supreme Court of Canada by Strong, J. in St. John v. Rykert (1884) 10 S.C.R. 278. At p. 288 he said:
'.. and I should have thought that a proper and salutary construction, requiring as it does parties who stipulate for a larger amount of interest than the usual and legal rate to make clear by precise and unambiguous language what their intention was.'

Moreover, the Canada Permanent decision is all the more unexpected given that the same learned Justice, Mr. Laycraft, was speaking for the Court in both decisions: the present one disallowing post-judgment interest beyond $5 \%$, and the previous unreported one allowing it if properly drafted.

Though neither side has (yet) received any notification of an intention to appeal to the Supreme Court of Canada in the instant case, another appellate decision, from Manitoba, did very recently receive leave to appeal to the Supreme Court, ${ }^{14}$ on the issue of whether one can contract out of s. $10(1)^{15}$ of the Canada Interest Act. The Supreme Court of Canada has not yet heard this appeal.

The remedy may lie, as the learned Justice now asserts, with Parliament. Parliament is not however likely to provide an overly expeditious solution. The perceived screw-tightening of debtors by permitting or raising post-judgment interest beyond $5 \%$ is unlikely to be received as socially philanthropic, or politically sagacious, legislation. Indeed the learned Justice herein comments upon the origins of the present Interest Act being in the repeal of the usury laws. ${ }^{16}$

A more likely source of legislative reversal will be the Charter of Rights - section 13 of the Interest Act applies only to the four Western Provinces and the Territories. ${ }^{17}$ It is hence inevitably only a matter of time

12. Bank of Nova Scotia v. U.P.C. Holdings Ltd., supra note 2, and Maple Credit Ltd. v. Xomox Investments Ltd. et al., supra note 2; at p. 43 of the Judgment.

13. Zero Stores (Sask.) Ltd. v. K.A.H. Investments, supra note 2 at p. 10. The Court did however go on to state that "We are not prepared to hold that the language in this case is sufficiently explicit to override the provisions of section 13, assuming for the purposes of this case that the section can be so overridden, a point which we do not decide".

14. Potash v. Royal Trust Company (1984) 28 Man. R. (2d) 1 (Man. C.A.). Leave was granted on July $26,1984$.

15. With regard to interest chargeable in real estate mortgages payable more than 5 years after the date of the mortgage.

16. Supra, note 3, p. 44.

17. By virtue of s. 12 of the Interest Act. 
before section 13 is challenged on the basis of s. 15(1) of the Canadian Charter of Rights and Freedoms: ${ }^{18}$

Every individual is equal before and under the law and has the right to the equal protection and equal benefit of the law without discrimination ...

In the interim, a potential creditor can at least ensure that the recovery of solicitor-and-client costs are contracted for in advance, and drafted in such a way as to permit recovery as part of the judgment, ${ }^{19}$ the more recently-realistic Schedule $\mathrm{C}^{20}$ for party-and-party costs notwithstanding. If a potential debtor is content with attempting to out-manoeuvre and delay a judgment, in the knowledge that interest at only $5 \%$ need ultimately be paid (and invest funds at a higher rate in the meantime), the knowledge that he will thereby eventually be responsible for paying the solicitor-and-client costs of both sides of his self-generated delay, may have a salutary effect. ${ }^{21}$

18. Constitution Act, 1982, Part 1, as enacted by the Canada Act, 1982, (U.K.) c. 11. By section 32(2) of the Constitution Act, section 15 will not be ef fective until April 17, 1985.

19. Party-and-party costs are the rule in Alberta unless solicitor-and-client costs have been contracted for in advance: Signature Finance Ltd. v. Halmosi et al., unreported, 27 May 1982 (Alta. Q.B., M.C.).

In the following cases, in which the nature of the action is specified, solicitor-client costs were properly contracted for: Ram Mortgage Corporation (1973) Ltd. v. Huizingh et al. (1984) 48 A.R. 209 (Alta. Q.B., M.C.) (mortgage - here it was stated that solicitor-client costs must be expressly contracted for, be pleaded in the statement of claim and prayer for relief, and spoken to in Court initially or leave sought until later); Bielous Holdings Ltd. v. 255698 Alberta Ltd. (1984) 45 A.R. 6 (Alta. Q.B., M.C.) (mortgage); Royal Trust Corp. of Canada v. Consolidated Investments [1984] Alta. D. 2768-03 (Alta. Q.B.) (mortgage); Canada Trustco Mortgage Companyv. 112293 Holdings Ltd. et al. [1984] Alta. D. 2779-01 (Alta. C.A.) (mortgage); Laurentide Financial Services Ltd. v. Bickert et al. (1983) 44 A.R. 237 (Alta. Q.B., M.C.) (mortgage); Kalke et al. v. 213156 Holdings Ltd. (1983) 47 A. R. 215 (Alta. Q.B.) (mortgage); Bank of Montreal v. Kavich et al. [1983] Alta. D. 2768-21 (Alta. Q.B., M.C.) (mortgage); Nay et al. v. Fielder et al. [1983] Alta. D. 2768-1I (Alta. Q.B., M.C.) (mortgage); First Investors Corp. Ltd. v. 121925 Enterprises Ltd. [1982] Alta. D. 2768-06 (Alta. Q.B., M.C.) (mortgage); First Investors Corp. Ltd. v. J.D. Bond Investments Ltd. et al. [1982] Alta. D. 2770-04 (Alta. Q.B., M.C.) (covenant only by corporate mortgagor with regard to solicitor-client costs, not individual mortgagor); Brugger v. Cardinal et al. [1982] Alta. D. 2768-03 (Alta. Q.B., M.D.) (mortgage); Morguard Trust Co. v. Doonanco [1981] Alta. D. 2765-02 (Alta. Q.B., M.C.) (mortgage); Central Mortgage and Housing Corporation v. Conaty (1967) 59 W.W.R. 11 (Alta. C.A.) (mortgage).

In these cases, solicitor-client costs were not, or not properly, contracted for in advance (and therefore not granted): Royal Bank of Canada v. Smith et al. (1982) 21 Alta. L.R. (2d) 12 (Alta. Q.B.) (chattel mortgage); Signature Finance Ltd. v. Halmosi et al., unreported, 27 May 1982 (Alta. Q.B., M.C.) (promissory note); Canadian Acceptance Corporation Lid. v. Color Developments Ltd. et al. [1982] Alta. D. 3590-01 (Alta. Q.B., M.C.) (conditional sale contract).

20. Alta. Reg. 134/84. Ef fective Sept. 1, 1984

21. See further, E. Meehan and P. Vaartnou, Creditors' Remedies - Alberta Law and Practice, Chapter 4, "Statements of Claim"' (in press, Carswell, 1984). 